\title{
Life Cycle Assessment of Domestic Hot Water Systems: A Comparative
}

\author{
Analysis \\ Poorang Piroozfar ${ }^{1,2^{*}}$, Francesco Pomponi ${ }^{1}$, Eric R.P. Farr ${ }^{3}$ \\ ${ }^{1}$ School of Environment and Technology, University of Brighton, Cockcroft Building, Brighton, BN2 4GJ, East \\ Sussex, UK \\ @BEACON (Advanced Technologies in Built Environment, Architecture and CONstruction), School of \\ Environment and Technology, University of Brighton, Cockcroft Building, Brighton, BN2 4GJ, East Sussex, UK \\ ${ }^{3}$ NewSchool of Architecture and Design, 1249 F Street, San Diego, CA 92101, USA
}

\section{Abstract}

On average, hot water is responsible for $18 \%$ of residential energy consumption and corresponding greenhouse gas (GHG) emissions. Several domestic hot water systems (DHWSs) are commonly used but their life cycle impacts are yet to be established comprehensively. This is due to those impacts varying significantly within the context and the system boundaries of the assessment. This article reports findings from a comparative cradle-to-grave life cycle assessment (LCA) of five DHWSs in the UK context.

Primary data acquired from a case study contributed to achieving accurate life cycle inventories that were then modelled in SimaPro through the ecoinvent database. Global Warming Potential (GWP) is the impact assessment method used. Amongst the five types, solar heater with electric backup appears to be the least damaging alternative. The study also reinforces the importance of adopting a cradle-to-grave approach if LCA results are to accurately reflect environmental impacts holistically and lead to better, more informed decisions.

Keywords: Domestic Hot Water Systems, Life Cycle Assessment, Life Cycle Inventory, Life Cycle Impact Assessment, Solar Heater

\section{Introduction}

Among building services a key role is played by the hot water system, which accounts for about $18 \%$ of the energy use of a home (EIA, 2013). As a consequence of global energy crisis in the late 1970s followed by concerns about the environment and global warming, there has been a continuous development of water heating technologies, mainly through gas and solar energy.

Solar energy is undoubtedly the most abundant energy source on Earth. If $0.1 \%$ of the solar radiation reaching the Earth's surface was converted into electric power, with $10 \%$ efficiency, it would generate four times the current global energy production (Thirugnanasambandam et al., 2010). However, $80 \%$ of the energy used today comes from non-renewable sources, bringing out a contradiction that should not exist (Thirugnanasambandam et al., 2010). Many countries are already using solar energy at a large scale in order to reduce their dependence on fossil fuels and cut their greenhouse gases (GHG) emissions. However, this renewable source has its downsides. Its availability is

\footnotetext{
*Corresponding author; Email: a.e.piroozfar@brighton.ac.uk, Tel: +44(0)1273 642421
} 
sporadic, and with current technologies this means it cannot meet the hot water demand throughout a whole day or a whole year. Therefore, hybrid technologies have been created to address this shortcoming, like the solar heating with electric support system. Research shows that switching from electric shower to these hybrid technologies can save up to $70 \%$ of energy used for providing hot water and up to $36 \%$ in total energy consumption of a residence (Altoé et al., 2012).

The figures above normally take into account primarily the use phase of the hot water systems. Although life cycle assessment (LCA) studies do exist with respect to domestic hot water systems (DHWSs), a cradle-to-grave comparative LCA in the context of the UK is missing, and this is the gap that this article aims to fill. Thus far, only two studies have focused on DHWSs in the UK (Allen et al., 2010; Greening \& Azapagic, 2014), but both are chiefly related to solar hot water systems. Practical implications of this research will point towards the option(s) with lower environmental impacts, within the chosen system boundaries, thereby enabling designers, builders, suppliers and manufacturers to achieve better levels of environmental-friendliness and improve their awareness of the sustainability of the products they produce or specify. Such an outcome may in turn also contribute to higher awareness in the fields of building certification and rating, as well as energy policies, within the boundaries of this research. Additionally, as a secondary objective, this article shows the need for an enhanced clarity in the LCA field, discussing the results from the aforementioned cradle-to-grave perspective, and also a cradle-to-gate one. It is important to notice that although ISO standards clearly label cradle-to-gate studies as neither life cycle assessment nor life cycle inventories (ISO, 2006a), still too often, cradle-togate approaches bear the 'life cycle' connotation (Ip \& Miller, 2012). This second objective also reinforces the necessity for enhanced clarity in LCAs of building components if environmental impacts are to be established holistically.

\section{Literature Review}

DHWS has been the focus of many studies. However, hardly ever have even two studies taken the same methodology or selected the same samples. Many researchers have taken different approaches in different context or in geographical settings, using different equipment configuration to approach LCA of DHWSs. In this section the leading research in the field is reviewed with an aim to set the scene for investigating further the possibilities, benefits and limitations of the approaches and to position the present work within the wider context of the research in this field.

\subsection{Comparative studies}

A study conducted to evaluate the environmental impact of water heating systems using electric, gas and solar heaters - through LCA in domestic projects in Brazil shows that electric shower and solar system with gas heaters are the systems with the highest and the lowest impacts correspondingly (Taborianski, 2002). It is not however, unreasonable to assume that this is subject to significant change as the production process of solar heater systems has improved massively ever since this study was carried out.

LCA has been used in order to evaluate solar DHWSs and compare them with electricity and natural gas (Tsilingiridis et al., 2004) where environmental impacts associated with the production and utilization of solar DHWSs were assessed using Eco-Indicator 99. 
The solar DHWS has a net gain of 696-2117 environmental impact points over electrical heaters, depending on the size of the system. The gain is shown to have been reduced by a factor of 4 when electricity is replaced by natural gas. The study also showed that among the materials used in solar DHWSs, steel and copper have major contributions to the overall impact.

It has been shown that the embodied energy component of the net energy requirement of solar and conventional hot water systems was insignificant in a study carried out in Melbourne, Australia, over a 10-year period, the typical warranty period of hot water systems (Crawford \& Treloar, 2004). The solar hot water systems provided a net energy saving compared to the conventional systems after 0.5 and 2 years, for electricity- and gasboosted systems respectively. This can be compared with Crawford et al. (2003) who found that compared to the conventional systems, solar systems provide net emissions savings after 2.5-5 years in Melbourne and after 2.5 years in Brisbane, depending on the auxiliary fuel and the life-cycle cost analysis which also revealed that the financial payback period for solar hot water systems is more than 10 years in Melbourne and around 10 years for an electricity-boosted system in Brisbane.

Though it might seem obvious that the environmental impacts of solar systems are always considerably less than that of the options that use electricity, to further confirm the findings by Koroneos and Nanaki (2012), it was shown in another study by Martinopoulos et al. (2013) that the solar hot water systems may have a lower impact than other heating options when considering the whole life cycle of the product, hence the systems with the best performance through their life cycle are not necessarily the same as those with less environmental impacts in production and manufacturing processes. This is due to much higher impact of substituted electricity in use phase which exceeds the small differences in the other stages. This research suggests

\subsection{Solar Domestic Hot Water Systems (Solar DHWSs)}

An LCA of a solar thermal collector, where an overall primary energy consumption of 11.5 GJ was calculated for extraction, production process, installation, maintenance, transports and disposal, suggests that $5 \%$ of this energy was used for manufacturing the collectors, $6 \%$ for transportation during different life cycle phases and the rest for production of raw materials (Ardente et al., 2005a). Ardente et al. (2005a) also show that the embodied energy associated with collector and water tank is the highest during the life cycle while by contrast energy and $\mathrm{CO}_{2}$ payback times were less than 2 years confirming the great environmental convenience of this technology.

A sensitivity analysis study suggests that a great uncertainty exists regarding aluminium, copper, thermal fluid and galvanized steel, the dominant materials used in Solar Hot Water Systems (SHWSs), where other life cycle steps (transports, installation and maintenance) also cause large impacts (Ardente et al., 2005b). Despite high uncertainty, the study concludes that supposing a loss of efficiency up to $40 \%$, it is estimated that, even in pessimistic scenarios, the energy and emission payback times are lower than 4 years. They argue for a positive qualitative judgement regarding the environmental performances of the collector that is not sensibly influenced by all the study uncertainties (Ardente et al., 2005b).

Life cycle analysis of a solar thermal system with thermochemical storage process, where an alternative efficient solar heating/cooling system based on a pair of salt-water 
endothermic/exothermic reaction was introduced, suggests that producing $1 \mathrm{GJ}$ energy equates global warming potential of $6.3-10 \mathrm{~kg} \mathrm{CO}$, acidification potential of $46.6-70 \mathrm{~g} \mathrm{SO}_{2}$, eutrophication of 2.1-3.1g phosphate and photochemical oxidant of $0.99-1.5 \mathrm{~g} \mathrm{C}_{2} \mathrm{H}_{4}$ (Masruroh et al., 2006). The raw material acquisition and components manufacturing processes contribute $99 \%$ to the total environmental impacts. It is claimed that the new system provides a considerably better solution for reduction of negative environmental impacts by using solar energy more efficiently (Masruroh et al., 2006).

Another study of thermal performance, economic and environmental life cycle analysis of thermosiphon solar water heaters in Nicosia, Cyprus suggests that apart from the economic and payback benefits, such solar water heater systems also offer benefits with respect to life cycle assessment of the systems (Kalogirou, 2009). The energy spent for the manufacturing and installation of the solar systems is recuperated in about 13 months, and it takes from a few months to 3.2 years (depending on the fuel and the particular pollutant considered) to compensate for the emissions pertaining to the embodied energy (Kalogirou, 2009).

Allen et al. (2010) carry out a study where they consider only a gas-fired boiler as the auxiliary heating system for SHWS, and further follow up their investigation where SHWS is installed alongside three auxiliary systems: a gas boiler, oil boiler, and electrical immersion heater. For these three systems they show that the SHWS would payback its embodied energy in 0.7-2.4 years, and its embodied carbon within 2 years. It was also shown that the use of aluminium has the greatest impact in the production process of the system. Their economic assessment asserts that the SHWS is currently uncompetitive, however, future prospects for reduced capital costs may suggest improved economic justification (Allen et al., 2010).

A longitudinal study of solar DHWSs use in Greece over 30 years (1978-2007) suggests that steady improvement in technology and production process of SHWSs has resulted in enhancement in their performance (Tsilingiridis \& Martinopoulos, 2010). It also suggests that the climate change targets set by the Greek government have been exceeded by $76 \%$, from $21.27 \mathrm{GWh}_{\mathrm{el}}$ in 1978 to $1513 \mathrm{GWh}_{\mathrm{el}}(2.4 \%)$ in 2007 . They also investigate scenarios for future development in share of renewable solar energy in domestic hot water provision and speculate the potential capacity of installing new solar hot water systems which is then used to estimate the potential extents to which energy can be saved and $\mathrm{CO}_{2}$ emissions can be reduced (Tsilingiridis \& Martinopoulos, 2010).

Net energy analysis of domestic solar DHWSs in Ireland aimed at building on the real performance of installed systems in operation reviews those systems from a life cycle perspective (Hernandez \& Kenny, 2012). The study confirms the findings of previous studies in that measured performance of domestic solar water heating systems can be lower than predicted. The study finds the energy payback based on the expected energy savings to be between 1.2 and 3.5 years, values comparable to previous studies but also suggests that the measured energy savings generally worsen the life cycle energy performance of this technology and thus increase the energy payback period. The study concludes that while there is a real potential for life cycle energy savings through solar DHWS installations, devising mechanisms to ensure proper design, installation and operation of systems are in place, is essential for this technology.

More recently a specific solar water heater was also studied taking into account the production process of raw materials - i.e. steel, glass, copper, aluminium, glass fibre and polyurethane insulators - the manufacturing process of the various parts of the system, and 
finally the assembly process (Koroneos \& Nanaki, 2012). The emissions were calculated using the Eco-Indicator 99 and the main environmental impact of the system is due to ecotoxicity, more specifically acidification reaching up to 54\%. The contribution to the Global Warming Potential (GWP) due to $\mathrm{CO}_{2}$ emission has also been presented, although significantly lower at only $12 \%$ (Koroneos \& Nanaki, 2012).

The LCA and LCC [Life Cycle Costing] of solar water heating systems has been studied for U.S. typical residential buildings in three different geographical locations, for two different types of solar collectors (flat-plate and evacuated-tube solar collectors), and two types of auxiliary systems (natural gas and electricity), where the flat-plate solar water heating systems using natural gas auxiliary heater was shown to have the best performance among all the types and at all locations (Hang et al., 2012). The energy and environmental payback periods are less than half of a year, and the life cycle cost payback vary from 4 to 13 years in different locations and for different configurations (Hang et al., 2012).

A recent study has been carried out to assess environmental impacts of solar DHWSs considering some impact categories and the energy pay-back time (EPBT) where 32 different types of SHWSs were considered (7 SHWS configurations, 4 different fuels for the auxiliary systems and 4 base cases without SHWSs) to meet the daily heating energy for hot water demand of two dwellings and 2 hotels, located in Aragón, Spain over a 20-year period (Zambrana-Vasquez et al., 2015). The results show that the use of biomass has some environmental benefits over other fuels in terms of $\mathrm{kg} \mathrm{CO}_{2}$. It is also shown that the use phase of the system is the one that contributes the most to the impact categories and that biomass has a higher value of EPBT. The paper suggests that final decision should be made based on a comparison between different benefits offered with regards to environmental impacts and EPBT.

Suffice to say, not all the studies have used same methodologies or have similar focus, hence different results. Some highlight solar systems as the most environmentally friendly system, whereas others prove otherwise. These results can differ, for example, due to availability of fossil fuels and electricity generation within the study region. The results also depend on the boundaries, limitations and scopes of the LCA in each study. Limitations of some studies, regardless of the validity and reliability of their results, render them as very case-specific researches where no or very little further generalization can be made. Some by contrast try to take into account the generalization factor but miss to provide full coverage of different systems. It is important to note that LCA studies for obvious reasons are bound to be carried out within a particular geographical location, and the current study is no exemption. Given these inevitable contextual boundaries, this research attempts to take all the measures to ensure objective results are reached that are robust for validity and reliability tests.

\section{Research Methodology and Design}

This research uses a single-case study with multiple-unit of analysis to investigate different DHWSs in a live building project. Although primarily considered qualitative, case study research utilizes both qualitative and quantitative research methods (Bryar, 2000). In case of current research which is heavily relying on quantitative data in its different units of analysis, as a case study it is still believed to belong to a constructivist paradigm (Stake, 1995). Yin (2009, p.38) strengthens the methodological legitimacy of case studies by arguing that a "fatal flaw in doing case studies is to conceive of statistical generalization as the method of generalizing the results of the case study" because cases are not sampling units 
and should be treated as experiments (Tsang, 2014). The primary strength of case study research is its reliance on data enquiry from different sources and multiple data collection techniques. This increases the validity of findings (Newman \& Ridenour, 2008) hence the approach of this research, where tested and approved methods for enquiring and analysing data commonly utilized in LCA through its two middle stages, namely life cycle inventory (LCI) as data acquisition, and life cycle impact assessment (LCIA) as data analysis, have been employed.

A Life Cycle Assessment (LCA) is the compilation and evaluation of the inputs and outputs and the potential environmental impacts of a product system throughout its life cycle (ISO, 2006a, 2006b). System boundaries generally span from extraction of raw materials to the end of production stage (cradle-to-gate study), or to final disposal of the product when it comes to end of its service life (cradle-to-grave study). The methodological framework consists of four phases; as seen in Figure 1.

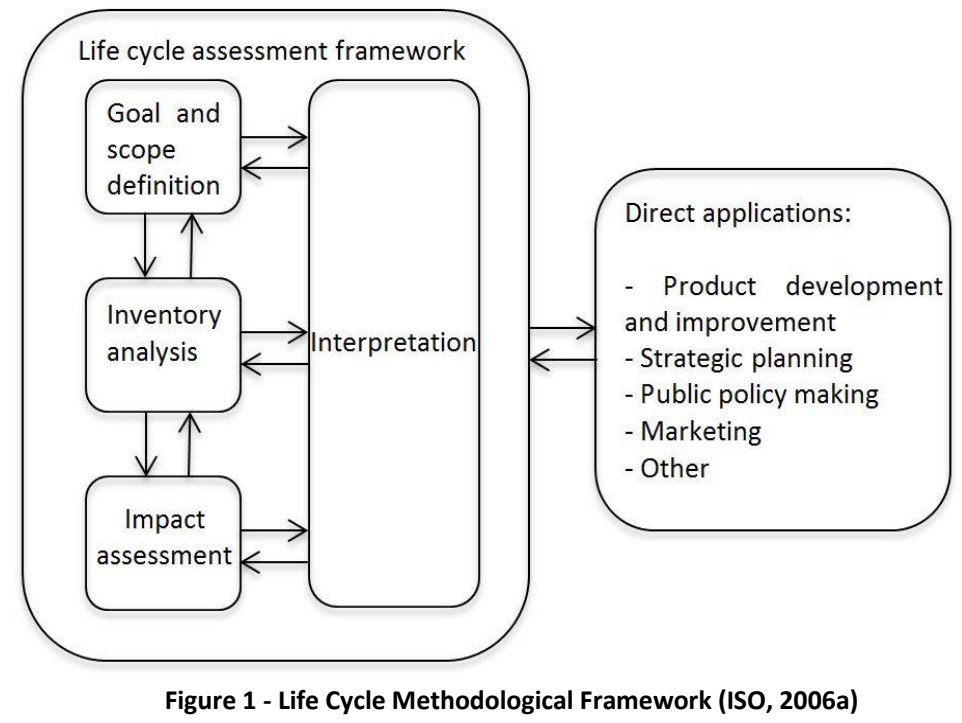

The first phase deals with defining the goal and the scope of the study, the system

\subsection{Goal and Scope}

The goal of this assessment is to gauge the environmental impacts of different types of residential water heating systems in order to identify:

a) the contribution of different life cycle stages within each system studied, thus highlighting the phases which bear the highest environmental loads, and

b) the system with the lowest environmental impacts (i.e. the least damaging alternative)

The focus is on the amount of GHGs emitted during the entire life cycle. Such an impact category addresses climate change related impacts and the method used is the GWP indicator over a period of 100 years (IPCC, 2013). The LCA tool used throughout this study is 
SimaPro 8.0.3.14 equipped with ecoinvent 2013, the world's leading double peer-reviewed database with consistent and transparent, up-to-date LCl data (Weidema et al., 2013).

The study is conducted for a typical four-storey multi-family domestic building. More specifically, a modular building has been chosen (Figure 2), defined as a construction method where individual modules, stand-alone or assembled together, make up larger structures (MBI, 2009).

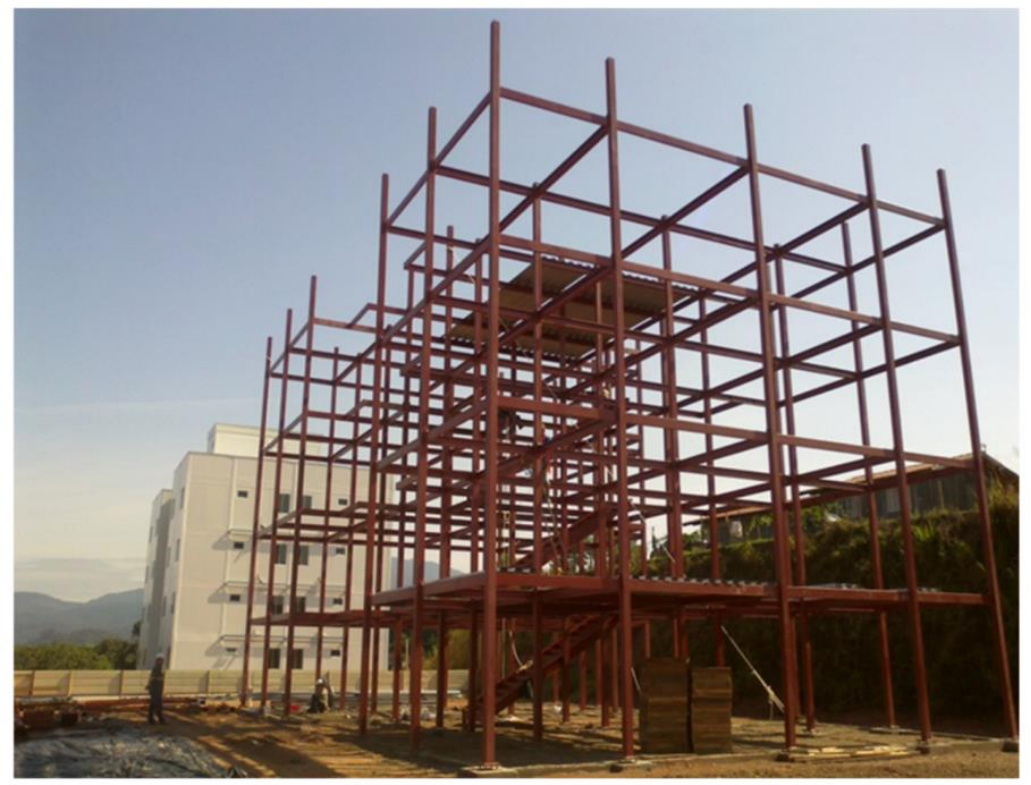

a)

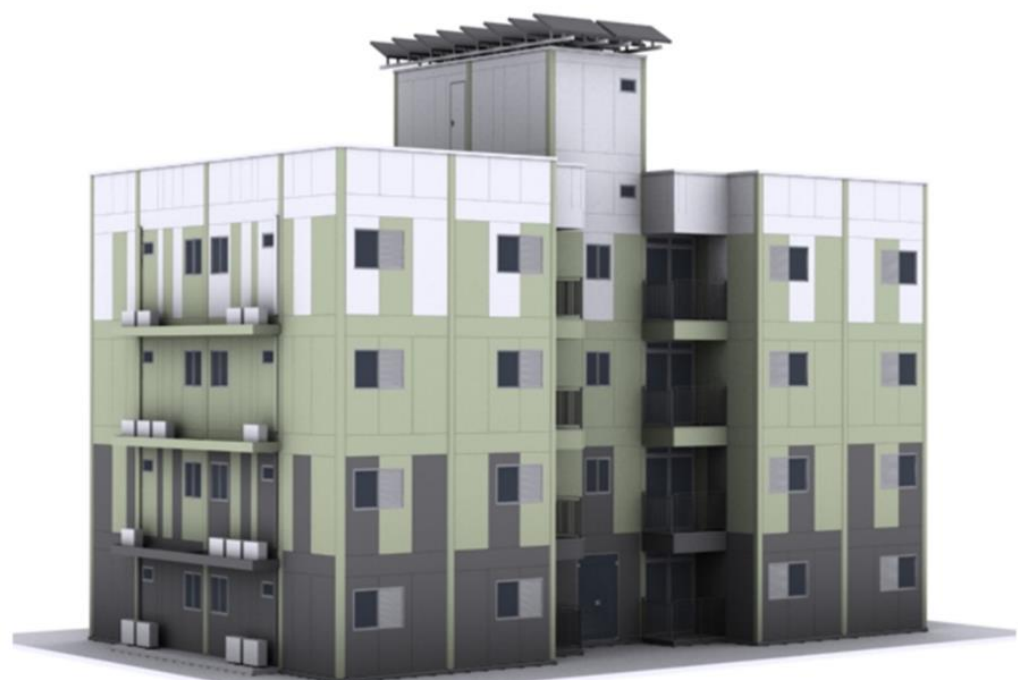

b)

The reason for such a choice is that modular buildings are quickly gaining momentum in the AEC industry due to "fast delivery, reduced environmental impact, ease of relocation, low-cost reconfiguration, and enormous flexibility" (MBI, 2009, p. 2). The case considered in here consists of 16 apartments and is supposed to be located in city of Brighton and Hove, South East England. The other reasons for selection of this case study include:

- Global dimensions of the design scheme which make it suitable to be used above and beyond its supposed geographical location in South East England 
- Its suitability for modern contemporary life style

- Its clear spatial layout which makes the intended M\&E easy to implement and the swap between the systems easy with no further need for major additional intervention which may bear unnecessary impacts on LCA

- Offering possibilities to accommodate the intended technologies (on the flat roof)

- The legibility, transparency and ease of the structural system proposed here (Figure $2 b)$, makes the end product equally fit for purpose for accommodating different standards and specifications ranging from social housing to high-end boutique flats with no impact on the selected hot water system.

As highlighted in the literature review, the most used hot water systems are electric and gas boilers, solar collectors and instantaneous systems (electric shower and passage heater with gas), hence they are the ones selected for evaluation in this study.

\subsection{Functional Unit, Systems, and System Boundaries}

283

284

285

286

287

288

289

290

291

292

293

294

295

296

297

298

299

300

301

302

303

304

305

306

307

308

309

310

The functional unit (FU) was defined as the production of 392448000 litres of heated water with a temperature of at least $37{ }^{\circ} \mathrm{C}$. Although older studies suggest shorter periods for an average shower time, a recent study by behavioural psychologists at Unilever UK and Ireland suggests that "the average shower is eight minutes long and uses nearly as much energy and water as a bath" (Unilever, 2011). For the specific purpose of the current study and to stay within a safe margin, it was assumed that a shower will last for 7 minutes with a $0.20 \mathrm{l} / \mathrm{s}$ flow rate and 4 showers a day ( 1 shower/day/inhabitant and 4 people living in each of the 16 apartments) over 20 years. The reference flow is the mass of each material used to provide the determined functional unit.

In accordance with LCA methodology, this is a cradle-to-grave study, which means that systems boundaries include the raw material extraction, materials production, supply (transport), use phase and disposal/end-of-life treatment. Use phase plays a key role in this analysis, since the systems work significantly differently from one another. The process of assembling parts of the heat units in the various manufacturing plants and the installation in-situ will not be taken into account due to the lack of good quality data. As a service life, it is assumed that the systems last for a 20-year period (where, in addition, replacement of parts for some systems at shorter intervals may be necessary). Transport distances are calculated based on a market research. For each material or component, the nearest extraction or production plant to the building site has been determined.

Full details of the following systems considered for this study are provided in the supporting material available online and linked to this article (Figures S2 through to S5, and Tables S1 through to S10):

- Electric shower

- Passage heater with gas

- Solar heater with electric backup

- Electric boiler; and

- Gas boiler 


\section{Life Cycle Inventory}

Water heater units form the major component of DHWSs. However, such systems are not merely limited to water heaters. Pipes, records, valves and accessories also form part of the system. Thus, the LCA for these systems is more complex, involving multiple devices with different types of materials.

The amount of each material/component in terms of mass $(\mathrm{kg})$ was taken into account in order to calculate the environmental loads of the whole life cycles of the nominal equipment which were selected for the purpose of this study.

\subsection{Electric shower}

7500 W Triton Seville (Figure ) was selected as the electric shower, because it has a low response time to provide good quality shower and has a high safety rate.

When an electric shower is used there is a significant increase in the energy demand. Thus, there is a need for a three-phase power supply and the use of a larger diameter for copper cables and conduits. Furthermore, it was necessary to provide a specific circuit for the electric shower. The representation, specification and quantification of the mechanical electrical and plumbing (MEP) components is given in Figures S3 and S4, and Tables S1 and S2 (online supporting material).

It is worth mentioning that much more ore at extraction phase is needed than the actual amount used in the final product since there is a significant loss due to quality of raw material which results in waste.

a)

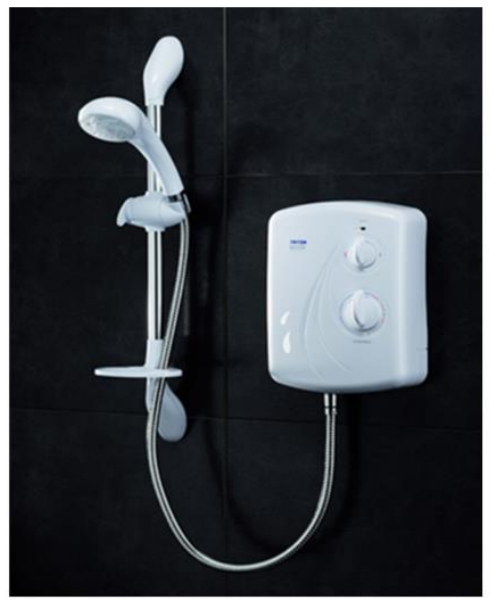

b)

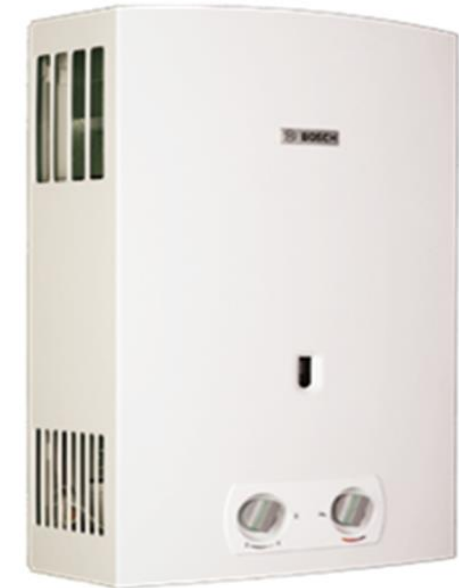

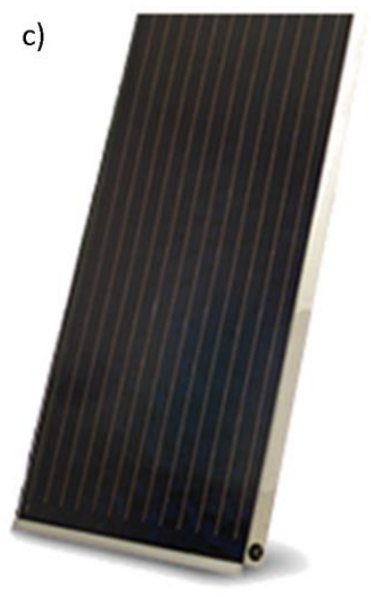

e)
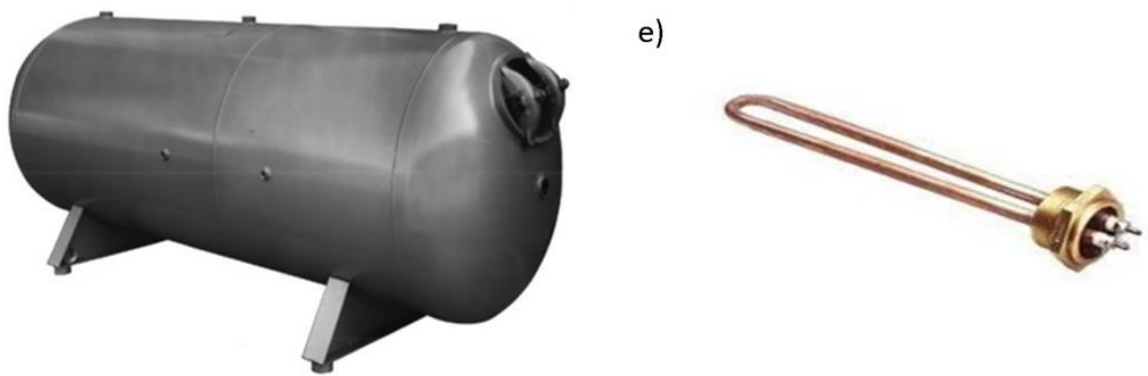
Supply is estimated as the total amount of components required for the system installation (around $1726 \mathrm{~kg}$ ) to arrive from factories within an average of $270 \mathrm{~km}$ distance, resulting in $1.726 \times 270=466 \mathrm{tkm}$.

By multiplying the amount of hours of the electric shower use by its power, the 339 energy demand for the use phase of the product can be calculated:

$\frac{408800 \mathrm{kWh}}{0.8}=511000 \mathrm{kWh}$ of low voltage at grid

The environmental impact depends on the percentage of production of the electricity plant types in the country. SimaPro has a database for Great Britain, so national figures are taken into account.

Same principles apply to disposal scenarios. SimaPro has a database with the waste scenario for England, so, $100 \%$ of the production was disposed of according to that scenario.

Table 1 shows the electric shower inventory:

Table 1 - Electric shower inventory

Extraction

\begin{tabular}{l|l|l}
\hline Material & SimaPro & Weight (kg/u) \\
\hline Copper & Copper, primary, at refinery & 3883.13 \\
Iron & Iron ore, 46\% Fe, at mine & 142 \\
Nickel & Nickel, 99.5\%, at plant & 64 \\
Chromite & Chromite, ore concentrate, at beneficiation & 25.6 \\
\hline Transformation & \multicolumn{2}{|l}{} \\
\hline Material & SimaPro & Weight (kg/u) \\
\hline Electrolytic copper & Copper, concentrate, at beneficiation & 33.7 \\
Iron ore beneficiation & Iron ore, 65\% Fe, at beneficiation & 85.5 \\
Steel mill & Steel, low-alloyed, at plant & 85.5 \\
Petroleum refining for PVC & PVC (suspension polymerization) E & 13673.8 \\
Electrolytic nickel & Nickel, secondary, from scrap recycling & 25.6 \\
Chrome & Chromium, at regional storage & 0.82 \\
Resistor alloy & Iron-nickel-chromium allow, at plant & 0.48 \\
\hline
\end{tabular}

Manufacturing

\begin{tabular}{l|l|l}
\hline Process & SimaPro & Weight (kg/u) \\
\hline Copper wires & Wire drawing, copper & 30 \\
PVC moulding & Injection moulding & 7056
\end{tabular}




\begin{tabular}{|c|c|c|}
\hline Resistor moulding & Metal working machine operation & 0.48 \\
\hline \multicolumn{3}{|l|}{ Supply } \\
\hline Transport & SimaPro & tkm \\
\hline $\begin{array}{l}\text { Electric shower } \\
\text { Copper wires } \\
\text { PVC }\end{array}$ & $\begin{array}{l}\text { Transport, lorry 16-32t, EURO3 } \\
\text { Transport, lorry 16-32t, EURO3 } \\
\text { Transport, lorry 16-32t, EURO3 }\end{array}$ & $\begin{array}{l}6.4 \\
8.6 \\
451\end{array}$ \\
\hline \multicolumn{3}{|l|}{ Use phase } \\
\hline Input & SimaPro & kWh \\
\hline Electricity & Electricity, low voltage, at grid/GB & 511000 \\
\hline \multicolumn{3}{|l|}{ Disposal scenario } \\
\hline Type & SimaPro & Allocation \\
\hline England & Waste scenario/Eng & $100 \%$ \\
\hline
\end{tabular}

\subsection{Passage heater with gas}

With a water flow of $12 \mathrm{l} / \mathrm{min}$, Bosch Comfort Line GWH 250 B ND (Error! Reference source not found.) was selected as a nominal product for passage heater with gas for its suitability, convenience and popularity for small residential buildings. Full details are available in Tables S3 and S4 (online supporting material).

Chlorinated polyvinyl chloride (CPVC) pipes have been assumed as hot water pipes in order to reduce the cost of components. Metal pipes were used just for the supply of gas to the equipment.

In this system, natural gas was assumed as the energy source for the heater. As it does not use electricity, the power supply can be single-phase wiring and with smaller diameters.

Supply is estimated as the total amount of components needed for the system installation (around $1426 \mathrm{~kg}$ ) coming from factories within an average of $280 \mathrm{~km}$ distance, adding up as $1.426 \times 280=400 \mathrm{tkm}$.

The heater maximum gas consumption is $2 \mathrm{~m}^{3} / \mathrm{h}$. By multiplying the amount of hours of use by its consumption, the energy demand for the use phase of the product can be calculated:

$2 \frac{\mathrm{m}^{3}}{h}\left(\frac{\left(7 \mathrm{~min} \times \frac{60 \mathrm{~s}}{\mathrm{~min}}\right)}{\frac{3600 \mathrm{~s}}{h}}\right) \times 64 \frac{\text { showers }}{\text { day }} \times 365 \frac{\text { days }}{\text { year }} \times 20$ years $=109013 \mathrm{~m}^{3}$ of natural gas

Table 2 shows inventory for the passage heater with gas supply. 
Extraction

\begin{tabular}{l|l|l}
\hline Material & SimaPro & Weight (kg/u) \\
\hline Copper & Copper, primary, at refinary & 10678.6 \\
Iron & Iron ore, 46\% Fe, at mine & 760 \\
Zinc & Zinc, primary, at regional storage & 218 \\
Alumina & Alumina, at plant & 15.68 \\
Bauxite & Bauxite, at mine & 39.36 \\
\hline
\end{tabular}

\section{Transformation}

\begin{tabular}{l|l|l}
\hline Material & SimaPro & Weight (kg/u) \\
\hline Electrolytic copper & Copper, concentrate, at beneficiation & 92.7 \\
Brass & Brass, at plant & 7.52 \\
Iron ore beneficiation & Iron ore, 65\% Fe, at beneficiation & 450.6 \\
Steel mill & Steel, low-alloyed, at plant & 450.6 \\
Petroleum refining for PVC & PVC (suspension polymerization) E & 12306.4 \\
Aluminium & Aluminium, primary, liquid, at plant & 7.84 \\
\hline
\end{tabular}

\section{Manufacturing}

\begin{tabular}{l|l|l}
\hline Process & SimaPro & Weight (kg/u) \\
\hline Copper wires & Wire drawing, copper & 82 \\
PVC moulding & Injection moulding & 6350 \\
Metals inside the heater & Metal working machine operation & 187.2 \\
\hline
\end{tabular}

\section{Supply}

\begin{tabular}{l|l|l}
\hline Transport & SimaPro & tkm \\
\hline Gas heater & Transport, lorry 16-32t, EURO3 & 50 \\
Copper wires & Transport, lorry 16-32t, EURO3 & 22 \\
PVC & Transport, lorry 16-32t, EURO3 & 328 \\
\hline
\end{tabular}

\section{Use phase}

\begin{tabular}{l|l|l}
\hline Input & SimaPro & MJ \\
\hline Natural gas & Heat, natural gas, at boiler modulating<100kW & 4218803 \\
\hline
\end{tabular}

Disposal scenario

\begin{tabular}{l|l|l}
\hline Type & SimaPro & Allocation \\
\hline England & Waste scenario/Eng & $100 \%$
\end{tabular}


Conventional thermosyphon was selected for solar heater with electric backup. It requires no water circulation pump. A thermal reservoir, a 1000-litre water tank located at least $0.5 \mathrm{~m}$ above the solar panels on the roof of the building, is also part of the system. Full details are available in Figure S5 and Tables S5 and S6 (online supporting material). The selected system consists of 10 SunMaxx TitanPowerPlus-SU2 solar panels (Figure 3c) equipped with a Parker Horizontal Storage Tank A-1000-HT (Figure 3d).

This system requires a device to drop pressure between the water tank and the thermal reservoir, in order to have a pressure difference at the entrance of the reservoir and avoid a backflow of hot water into the cold water reservoir. Copper pipes were used for the hot water network, since in the solar system the hot water temperature can exceed the maximum temperature that a plastic pipe can operate under.

For the solar heating, flat plate collectors were used with a total area of $20 \mathrm{~m}^{2}$. The radiation is captured during the sunny hours of a day, converted into heat then transferred to the water, which is stored for use when necessary. In situations with several days without sunlight or low irradiation, an auxiliary heater that uses electricity is considered as backup. This heater consists of a resistor located inside the hot water storage tank.

A $5000 \mathrm{~W}$ resistor (Figure 3 e was selected, since the 1000 l hot water tank proposed in this study requires such relatively high power. Thus, the electricity consumption during the use stage of the solar heating will be used only by the resistor to cover the solar energy fluctuation during a specific period of time.

Because of the increase in the power used by the system, the power supply will be three-phase and it was necessary to add a circuit to feed the resistor off the hot water tank.

Supply is estimated as the total amount of components needed for the system installation (around $2000 \mathrm{~kg}$ ) to be brought in from factories within an average of $280 \mathrm{~km}$ distance, giving $2 \times 280=560 t \mathrm{~km}$ as a result.

For the use phase the online Valentin Software was used (ValentinSoftware, 2014). For Brighton, $20 \mathrm{~m}^{2}$ of collectors with $30^{\circ}$ slope, facing south generates around $21686 \mathrm{kWh}$ per year, which is more than the water heating demand. However during winter or cloudy days, the resistor will be needed to meet the hot water demand. Assuming that the solar heater covers $80 \%$ of the showers, the resistor is still needed to cover $20 \%$ (Taborianski, 2002). So, by multiplying the number of use hours of the system by its power, the energy demand for the use phase of the product can be calculated as follows:

$5 \mathrm{~kW} \times\left(\frac{\left(7 \mathrm{~min} \times \frac{60 \mathrm{~s}}{\mathrm{~min}}\right)}{\frac{3600 \mathrm{~s}}{\mathrm{~h}}}\right) \times 64 \frac{\text { showers }}{\text { day }} \times 365 \frac{\text { days }}{\text { year }} \times 20$ years $\times 20 \%=54506 \mathrm{kWh}$

\section{Considering an efficiency of $80 \%$, the demand is:}

$\frac{54506 \mathrm{kWh}}{0.8}=68133 \mathrm{kWh}$ of low voltage at grid

Table 3 shows the solar heater inventory: 


\section{Extraction}

\begin{tabular}{l|l|l}
\hline Material & SimaPro & Weight $(\mathbf{k g} / \mathbf{u})$ \\
\hline Copper & Copper, primary, at refinery & 31634.4 \\
Iron & Iron ore, 46\% Fe, at mine & 59.36 \\
Cassiterite & Tin, at regional storage & 167.5 \\
Alumina & Alumina, at plant & 170.2 \\
Bauxite & Bauxite, at mine & 425.5 \\
\hline
\end{tabular}

Transformation

\begin{tabular}{l|l|l}
\hline Material & SimaPro & Weight (kg/u) \\
\hline Electrolytic copper & Copper, concentrate, at beneficiation & 274.6 \\
Iron ore beneficiation & Iron ore, 65\% Fe, at beneficiation & 3.56 \\
Steel mill & Steel, low-alloyed, at plant & 3.56 \\
Petroleum refining for PVC & PVC (suspension polymerization) E & 10340.3 \\
Glass wool & Glass wool mat, at plant & 33 \\
Glass & Flat glass, uncoated, at plant & 101 \\
Expanded polyethylene & Fleece, polyethylene, at plant & 23.8 \\
Aluminium & Aluminium, primary, liquid, at plant & 85.1 \\
\hline
\end{tabular}

\section{Manufacturing}

\begin{tabular}{|c|c|c|}
\hline Process & SimaPro & Weight $(\mathrm{kg} / \mathrm{u})$ \\
\hline Copper wires & Wire drawing, copper & 15 \\
\hline PVC moulding & Injection moulding & 5335.5 \\
\hline Copper pipes & Copper product manufacturing & 250 \\
\hline \multicolumn{3}{|l|}{ Supply } \\
\hline Transport & SimaPro & tkm \\
\hline Solar panels & Transport, lorry 16-32t, EURO3 & 95.2 \\
\hline Copper wires & Transport, lorry 16-32t, EURO3 & 4.2 \\
\hline Copper pipes & Transport, lorry 16-32t, EURO3 & 70 \\
\hline Storage tank & Transport, lorry 16-32t, EURO3 & 112 \\
\hline PVC & Transport, lorry 16-32t, EURO3 & 280 \\
\hline
\end{tabular}

Use phase

\begin{tabular}{l|l|l}
\hline Input & SimaPro & $\mathbf{k W h}$ \\
\hline Electricity & Electricity, low voltage, at grid/GB & 68133 \\
\hline
\end{tabular}

Disposal scenario

\begin{tabular}{l|l|l}
\hline Type & SimaPro & Allocation \\
\hline England & Waste scenario/Eng & $100 \%$
\end{tabular}




\subsection{Electric boiler}

The same auxiliary system as explained in the above option was selected for this option too, that is a thermal reservoir with 1000 litres Parker Horizontal Storage Tank A$1000-\mathrm{HT}$ (Figure $3 \mathrm{~d}$ ) with a $5000 \mathrm{~W}$ resistor (Figure 3e).

Again, the system requires a device for pressure regulation between the water tank and the thermal reservoir, copper pipes were used for hot water network and the power supply will be three-phase, with a specific circuit to feed the resistor for the hot water tank. Full details are given in Tables S7 and S8 (online supporting material).

Supply is estimated as the total amount of components needed for the system installation (around $1568 \mathrm{~kg}$ ) to be transported from factories within an average of $255 \mathrm{~km}$ distance, which will result in $1.568 \times 255=400 \mathrm{tkm}$.

Assuming that the boiler works for 4 hours a day, multiplying the hours of its use by its consumption, the energy demand for the use phase of the product can be calculated at:

$$
5 \mathrm{~kW} \times 4 \frac{\text { hours }}{\text { day }} \times 365 \frac{\text { days }}{\text { year }} \times 20 \text { years }=146000 \mathrm{kWh}
$$

And considering an efficiency of $80 \%$, the demand will be:

$\frac{146000 \mathrm{kWh}}{0.8}=182500 \mathrm{kWh}$ of low voltage at grid

Table 4 shows the electric boiler inventory:

Table 4 - Electric boiler inventory

\section{Extraction}

\begin{tabular}{l|l|l}
\hline Material & SimaPro & Weight (kg/u) \\
\hline Copper & Copper, primary, at refinery & 20781.9 \\
Iron & Iron ore, 46\% Fe, at mine & 35.5 \\
Alumina & Alumina, at plant & 105.6 \\
Bauxite & Bauxite, at mine & 221.8 \\
\hline
\end{tabular}

Transformation

\begin{tabular}{l|l|l}
\hline Material & SimaPro & Weight (kg/u) \\
\hline Electrolytic copper & $\begin{array}{l}\text { Copper, concentrate, at beneficiation } \\
\text { Iron ore, 65\% Fe, at beneficiation } \\
\text { Iron ore beneficiation }\end{array}$ & 180.4 \\
Steel mill & Steel, low-alloyed, at plant & 2.13 \\
Petroleum refining for PVC & PVC (suspension polymerization) E & 2.13 \\
Expanded polyethylene & Fleece, polyethylene, at plant & 23.8 \\
Aluminium & Aluminium, primary, liquid, at plant & 52.8 \\
\hline
\end{tabular}

\section{Manufacturing}

\begin{tabular}{l|l|l}
\hline Process & SimaPro & Weight (kg/u) \\
\hline Copper wires & Wire drawing, copper & 15 \\
PVC moulding & Injection moulding & 5335.5
\end{tabular}




\begin{tabular}{|c|c|c|}
\hline Copper pipes & Copper product manufacturing & 150 \\
\hline \multicolumn{3}{|l|}{ Supply } \\
\hline Transport & SimaPro & tkm \\
\hline Copper wires & Transport, lorry 16-32t, EURO3 & 4.2 \\
\hline Copper pipes & & 42 \\
\hline Storage tank & Transport, lorry 16-32t, EURO3 & 112 \\
\hline PVC & Transport, lorry 16-32t, EURO3 & 280 \\
\hline \multicolumn{3}{|l|}{ Use phase } \\
\hline Input & SimaPro & kWh \\
\hline Eletricity & Electricity, low voltage, at grid/GB & 182500 \\
\hline \multicolumn{3}{|c|}{ Disposal scenario } \\
\hline Type & SimaPro & Allocation \\
\hline England & Waste scenario/Eng & $100 \%$ \\
\hline
\end{tabular}

\subsection{Gas boiler}

The system and considerations are the same as the electric boiler, but instead of using a resistor as a heating source, the water in the tank will be heated by a natural gas boiler.

The heater's maximum gas consumption is $2 \mathrm{~m}^{3} / \mathrm{h}$. So, under the assumption that the boiler works for 4 hours a day, multiplying the number of use hours by its consumption, the energy demand for the use phase of the product can be calculated:

$2 \frac{m^{3}}{h} \times 4 \frac{\text { hours }}{\text { day }} \times 365 \frac{\text { days }}{\text { year }} \times 20$ years $=58400 \mathrm{~m}^{3}$ of natural gas

Considering that each $\mathrm{m}^{3}$ of natural gas produces $38.7 \mathrm{MJ}$ of energy, the demand is:

$$
58400 \mathrm{~m}^{3} \times 38.7 \frac{\mathrm{MJ}}{\mathrm{m}^{3}}=2260080 \mathrm{MJ} \text { of heat from natural gas }
$$

Table 5 shows the gas boiler inventory.

Table 5 - Gas boiler inventory

\section{Extraction}

\begin{tabular}{l|l|l}
\hline Material & SimaPro & Weight $(\mathbf{k g} / \mathbf{u})$ \\
\hline Copper & Copper, primary, at refinery & 19561.6 \\
Iron & Iron ore, 46\% Fe, at mine & 35.5 \\
Alumina & Alumina, at plant & 105.6 \\
Bauxite & Bauxite, at mine & 221.8 \\
\hline
\end{tabular}

Transformation

\begin{tabular}{l|l|l}
\hline Material & SimaPro & Weight (kg/u) \\
\hline
\end{tabular}




\begin{tabular}{|c|c|c|}
\hline Electrolytic copper & Copper, concentrate, at beneficiation & $\mid 170$ \\
\hline Iron ore beneficiation & Iron ore, $65 \% \mathrm{Fe}$, at beneficiation & 2.13 \\
\hline Steel mill & Steel, low-alloyed, at plant & 2.13 \\
\hline Petroleum refining for $\mathrm{PVC}$ & PVC (suspension polymerization) E & 10340.3 \\
\hline Expanded polyethylene & Fleece, polyethylene, at plant & 23.8 \\
\hline Aluminium & Aluminium, primary, liquid, at plant & 52.8 \\
\hline \multicolumn{3}{|l|}{ Manufacturing } \\
\hline Process & SimaPro & Weight (kg/u) \\
\hline Copper wires & Wire drawing, copper & 15 \\
\hline PVC moulding & Injection moulding & 5335.5 \\
\hline Copper pipes & Copper product manufacturing & 150 \\
\hline \multicolumn{3}{|l|}{ Supply } \\
\hline Transport & SimaPro & tkm \\
\hline Copper wires & Transport, lorry 16-32t, EURO3 & 4.2 \\
\hline Copper pipes & Transport, lorry 16-32t, EURO3 & 42 \\
\hline Storage tank & Transport, lorry 16-32t, EURO3 & 112 \\
\hline PVC & Transport, lorry 16-32t, EURO3 & 280 \\
\hline \multicolumn{3}{|l|}{ Use phase } \\
\hline Input & SimaPro & MJ \\
\hline Natural gas & Heat, natural gas, at boiler modulating $<100 \mathrm{~kW}$ & 2260080 \\
\hline \multicolumn{3}{|l|}{ Disposal scenario } \\
\hline Type & SimaPro & Allocation \\
\hline England & \begin{tabular}{|l|} 
Waste scenario/Eng \\
\end{tabular} & $100 \%$ \\
\hline
\end{tabular}

\section{5. Life Cycle Impact Assessment and Interpretation of Results}

467 The embodied and operational carbon dioxide equivalent values of all the assessed 468 options are indicated in Table 6, in the form of $\mathrm{kg} \mathrm{CO}_{2 \mathrm{e}}$ and also as percentages of the total 469 impacts for each life cycle stages.

470 Five main life cycle stages have been identified other than the use phase, which are: 471 1) extraction of the raw materials, 2) transformation, 3) subsequent manufacturing, 4) 472 supply, and finally 5) disposal. These form what eventually accounts for the embodied 473 energy and embodied carbon.

Amongst those five, manufacturing is the one with more consistent share across the 475 five systems. To the contrary, extraction and disposal vary greatly depending on the specific 476 DHWS. Finally, transformation presents some variation as well-although in a more limited 477 range. 


\begin{tabular}{|c|c|c|c|c|c|c|c|c|c|c|}
\hline \multirow{3}{*}{$\begin{array}{l}\text { Life } \\
\text { Stages }\end{array}$} & \multicolumn{10}{|c|}{ Assessed DHW Systems } \\
\hline & \multicolumn{2}{|c|}{ Electric Shower } & \multicolumn{2}{|c|}{$\begin{array}{l}\text { Passage heater } \\
\text { with gas }\end{array}$} & \multicolumn{2}{|c|}{$\begin{array}{l}\text { Solar heater with } \\
\text { electric backup }\end{array}$} & \multicolumn{2}{|c|}{ Electric boiler } & \multicolumn{2}{|c|}{ Gas boiler } \\
\hline & $\mathrm{kg} \mathrm{CO} 2 \mathrm{e}$ & $\%$ & $\mathrm{~kg} \mathrm{CO} 2 \mathrm{e}$ & $\%$ & $\mathrm{~kg} \mathrm{CO} 2 \mathrm{e}$ & $\%$ & $\mathrm{~kg} \mathrm{CO} 2 \mathrm{e}$ & $\%$ & $\mathrm{~kg} \mathrm{CO}_{2 \mathrm{e}}$ & $\%$ \\
\hline Extraction & 12885.3 & $3.1 \%$ & 34192.4 & $8.36 \%$ & 102204 & $50 \%$ & 65280 & $27.2 \%$ & 61411 & $21.7 \%$ \\
\hline Transformation & 37279.8 & $8.9 \%$ & 34356 & $8.4 \%$ & 29376 & $14.4 \%$ & 28800 & $12.0 \%$ & 28866 & $10.2 \%$ \\
\hline Manufacturing & 9424.2 & $2.3 \%$ & 8711.7 & $2.1 \%$ & 7568.4 & $3.7 \%$ & 7392 & $3.1 \%$ & 7386.3 & $2.6 \%$ \\
\hline Supply & 208.5 & $<<1 \%$ & 207.5 & $<<1 \%$ & 204 & $<<1 \%$ & 96.2 & $<<1 \%$ & 113.2 & $<<1 \%$ \\
\hline Use & 349863 & $84 \%$ & 321065 & $79 \%$ & 46512 & $22.8 \%$ & 125040 & $52.1 \%$ & 172347 & $60.9 \%$ \\
\hline Disposal & 7631.1 & $1.8 \%$ & 10470.4 & $2.6 \%$ & 18217.2 & $8.9 \%$ & 13392 & $5.6 \%$ & 12876.5 & $4.6 \%$ \\
\hline Totals & 417291.9 & $100 \%$ & 409003 & $100 \%$ & 204081.6 & $100 \%$ & 240000.2 & $100 \%$ & 283000 & $100 \%$ \\
\hline
\end{tabular}

This specific detail of the results can be of useful in understanding, within each system, which life cycle stage is worth further investigation and closer attention in order to minimize the overall GHG emissions.

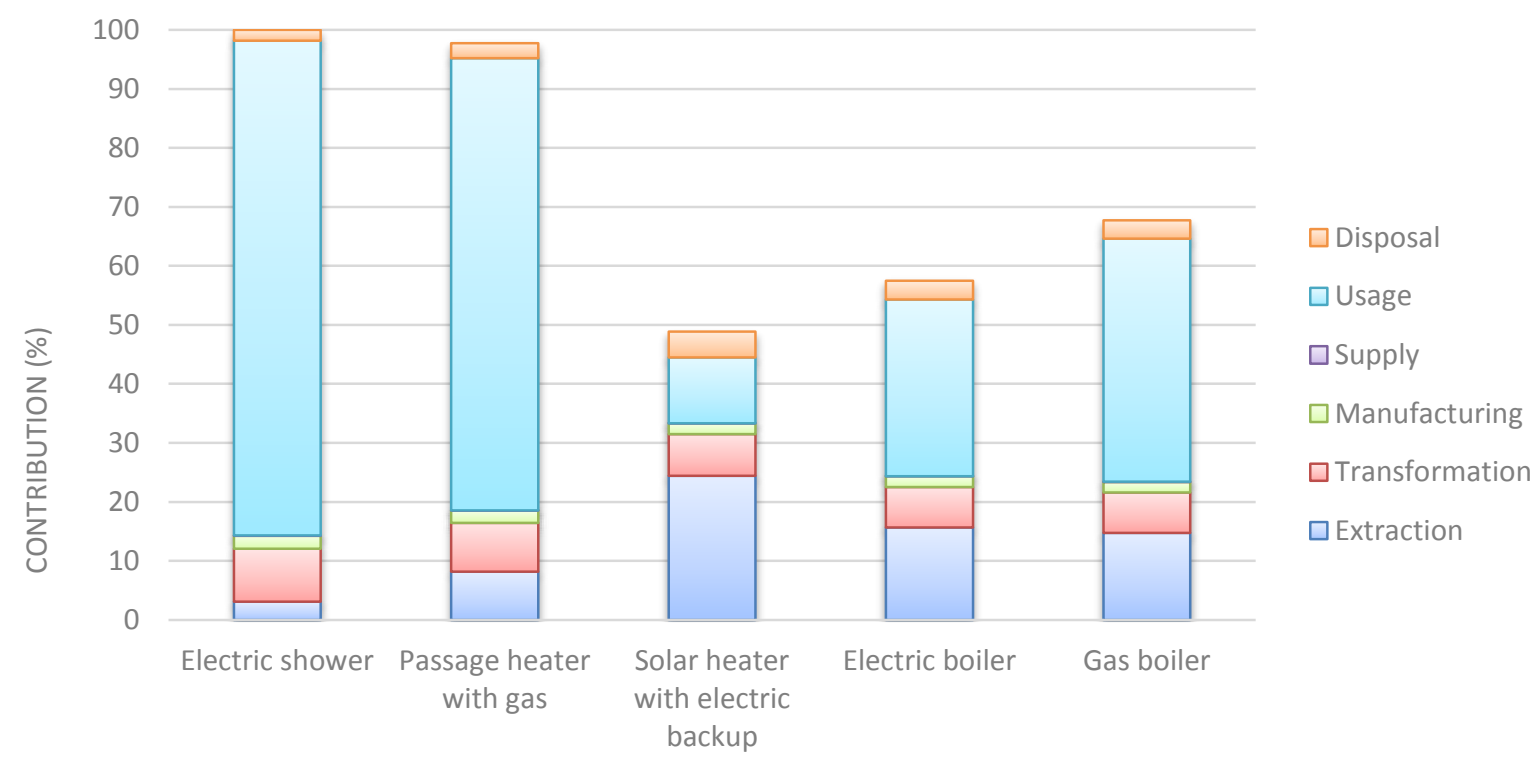

Figure 4 - Normalized percentage values of the impacts of different life cycle phases for the DHW systems considered

Numerical values in Table 6 have been reported in the form of bar charts in Figure 4, where percentages have been normalized. Results show that electric shower is the DHWS with highest environmental impact (benchmarked at 100\%), followed by passage heater with gas (98\%), gas boiler (68\%), electric boiler (57\%) and finally solar heater with electric backup (49\%). Therefore, given the assumptions, the system boundary, and the methodical choices of this study, solar heater with electric backup is the best option among the five to minimize adverse climate change impacts.

To contextualize findings from this research within other published studies, it is worth noting that Tsilingiridis et al. (2004) report solar heater as the best option, followed by gas and then electric devices whereas Taborianski and Prado (2004) indicate the electric shower as the most impacting system, followed by the solar system and eventually gas 
515

heaters as the best option. Both studies show different results from the present one. That is mainly due to the type of construction examined in the studies: housing vs. non-domestic buildings, and the geographical locations: Greece, and Brazil vs. Brighton. The climate, the energy mix, the availability of gas and other aspects are different in each country, thus making great differences in the final results.

However, it is extremely worth noting that such results heavily depend on the perspective used, which in this article is - once again - a cradle-to-grave. Indeed, had it been adopted a cradle-to-gate perspective results would have been completely different, as it is easy to spot from Figure 4.

In that case the solar system is the one that impacts the most, followed by the electric boiler with $73 \%$ of the solar system, then the gas boiler with $70 \%$, the passage heater with gas with $56 \%$ and the electric shower with $43 \%$. If DHW systems assessed were ranked from $1^{\text {st }}$ to $5^{\text {th }}$ the ranking from the cradle-to-gate would be the exact opposite of that from the cradle-to-grave study (Table 7).

Table 7 - Ranking of the five DHWSs assessed according to the LCA and the cradle-to-gate perspective

\begin{tabular}{l|c|c}
\multicolumn{1}{c|}{ DHWS } & $\begin{array}{c}\text { Cradle-to-gate } \\
\text { ranking }\end{array}$ & $\begin{array}{c}\text { Cradle-to-grave } \\
\text { ranking (LCA) }\end{array}$ \\
\hline Electric shower & $1^{\text {st }}$ & $5^{\text {th }}$ \\
Passage heater with gas & $2^{\text {nd }}$ & $4^{\text {th }}$ \\
Gas boiler & $3^{\text {rd }}$ & $3^{\text {rd }}$ \\
Electric boiler & $4^{\text {th }}$ & $2^{\text {nd }}$ \\
Solar heater with electric & $5^{\text {th }}$ & $1^{\text {st }}$ \\
backup & &
\end{tabular}

By observing Table 6 and Figure 4 it can be seen that the use phase - with its all preliminaries, assumptions, different life styles and personal or social norms and standards involved - play a major role in determining how environmentally friendly a DHWS is. Such a finding is in line with, for instance, those of Martinopoulos et al. (2013), highlighting that the predominant role of the use phase is true almost regardless of the context, despite that final results do seem to be context-dependant as discussed above with respect to Tsilingiridis et al. (2004) and Taborianski and Prado (2004).

Such a difference in the two assessments reinforces the importance of adopting a cradle-to-grave perspective when conducting an LCA as recommended in ISO standards (ISO, 2006a). In other words, all stakeholders in the AEC industry including manufacturers, suppliers, decision makers, legislators, developers, designers, contractors, clients and end users as well as those involved in post-occupancy phases involved in operation and maintenance and those in demolition and disposal/recycling/reuse phases should take a second look at how the environmental credentials of a building component or product has been carried out. In fact, a cradle-to-gate study may well lead to choose the most damaging alternative despite the probably genuine aim of identifying the least damaging one.

Due to the different distribution of environmental burdens within the assessed DHWSs it does make sense to think of environmental payback periods (EPBP). For instance, in comparing the electric shower and the solar heater (worst and best options from a cradleto-grave perspective), the greater embodied carbon of the latter is compensated by its 
operational carbon savings over the former just after $29.7 \%$ of the systems' lifespan. And with a service life of 20 years, it means that in just under 6 years, the solar heater will have paid back its greater embodied carbon and the net operational savings start with added benefits to the environment for the remainder of the system's service life.

Although contexts greatly vary from one study to the other, such value of EPBP is in line with other published figures of comparative studies involving solar hot water systems (e.g. Crawford et al., 2003).

\section{Conclusions}

The hot water system has a significant impact on energy consumption of a building. When well designed and controlled, it can play a major role in savings in energy and $\mathrm{CO}_{2}$ emissions. This research aimed to cast light on how to select a DHWS amongst five most commonly used types by using LCA to identify the least damaging alternative in terms of climate change related impacts through the global warming indicator chosen as the assessment method.

Within the contextual boundaries of this research, results indicate the solar heater with electric backup as a better option than all other ones - namely, electric shower, passage heater with gas, electric boiler and gas boiler. The advantage is achieved in the use phase of the system. While electricity and natural gas have a very high impact for the other four options, the solar heater takes profit of the solar irradiation to heat the water, as very clean and renewable source of energy for providing domestic hot water. However, findings of this research do not necessarily mean that a solar heater is always the best option. Firstly, it was analysed as a particular equipment in a particular building and in a specific site. When analysing, for instance, a residential house in Greece or an office building in Brazil, results could be significantly different. Secondly, economic viability of the considered options has not been assessed within this research in spite of financial considerations often impacting on if not driving the decisions in the choice of building products and systems. However, the trends observed within the cradle-to-gate and cradle-to-grave perspectives could potentially reflect the investment vs. running costs trade-offs. As such, solar systems tend to be more expensive as an investment (with higher initial costs) but with significant saving during use phase. However, this represents a topic that deserves a research on its own right through, for instance, Life Cycle Costing (LCC).

Although maximum care has been taken in order to ensure that a robust and valid research has been carried out, the use of estimation rather than primary data on the use phase (i.e. real consumption) and the lack of uncertainty analysis of the results surely represent some limitations of this study and, therefore, constitute interesting avenues for further research. Furthermore, different water heating systems, different buildings and different locations can be analysed in order to create a database for the best option for each specific situation.

The findings from this research can be practically useful to the stakeholders in the AEC industry-including manufacturers, suppliers, decision makers, legislators, developers, designers, contractors, clients and end users as well as those involved in post-occupancy phases involving operation and maintenance and those active in demolition and disposal/recycling/reuse phases - to understand the life cycle climate change impacts of five commonly used DHWSs holistically. Further, the breakdown of results into the most common life cycle stages can be of use in understanding, within each system, which life 
cycle stage is worth of further investigation and closer attention in order to minimize the overall GHG emissions.

Finally, this article has also confirmed that a full cradle-to-grave perspective must be adopted if LCA is to inform conclusions about environmental burdens. More specifically, had a cradle-to-gate perspective been adopted for the present, assessment results would have been the exact opposite of what they currently are. In this respect, findings from this research reinforce the plea for enhanced precision and a crystal-clear methodological approach in LCA such that shifts in environmental burdens from one life cycle stage to the other can be avoided.

\section{Acknowledgements}

The authors wish to thank Mr Marcel Vechi, MSc. who was instrumental in the data generation and helped with data analysis for this research under the Brazilian Science without Boarder Programme at the School of Environment and Technology, University of Brighton, UK, during the summer 2014. Special thanks also go to the editor-in-chief, associate editor(s), guest editor(s) and reviewers of International Journal of Construction Management, special issue on sustainable construction whose constructive comment helped further improve the quality of this paper.

\section{References}

Allen, S. R., Hammond, G. P., Harajli, H. A., McManus, M. C., \& Winnett, A. B. (2010). Integrated appraisal of a Solar Hot Water system. Energy, 35(3), 1351-1362. doi: http://dx.doi.org/10.1016/j.energy.2009.11.018

Altoé, L., Oliveira Filho, D., \& Carlo, J. C. (2012). Análise energética de sistemas solares térmicos para diferentes demandas de água em uma residência unifamiliar [in Portuguese]. Ambiente Construído, 12(3), 75-87.

Ardente, F., Beccali, G., Cellura, M., \& Lo Brano, V. (2005a). Life cycle assessment of a solar thermal collector. Renewable Energy, 30(7), 1031-1054. doi: http://dx.doi.org/10.1016/j.renene.2004.09.009

Ardente, F., Beccali, G., Cellura, M., \& Lo Brano, V. (2005b). Life cycle assessment of a solar thermal collector: sensitivity analysis, energy and environmental balances. Renewable Energy, 30(2), 109-130. doi: http://dx.doi.org/10.1016/j.renene.2004.05.006

Bryar, M. R. (2000). An examination of case study research. Nurse Researcher, 7(2), 61-78.

Crawford, R. H., \& Treloar, G. J. (2004). Net energy analysis of solar and conventional domestic hot water systems in Melbourne, Australia. Solar Energy, 76(1-3), 159-163. doi: http://dx.doi.org/10.1016/j.solener.2003.07.030

Crawford, R. H., Treloar, G. J., Ilozor, B. D., \& Love, P. E. D. (2003). Comparative greenhouse emissions analysis of domestic solar hot water systems. Building Research \& Information, 31(1), 34-47. doi: 10.1080/09613210210160800

EIA. (2013). Heating and cooling no longer majority of U.S. home energy use. Available at: http://www.eia.gov/todayinenergy/detail.cfm?id=10271 [Accessed August 2014] U.S. Energy Information Administration.

Greening, B., \& Azapagic, A. (2014). Domestic solar thermal water heating: A sustainable option for the UK? Renewable Energy, 63(0), 23-36. doi: http://dx.doi.org/10.1016/j.renene.2013.07.048 
Hang, Y., Qu, M., \& Zhao, F. (2012). Economic and environmental life cycle analysis of solar hot water systems in the United States. Energy and Buildings, 45(0), 181-188. doi: http://dx.doi.org/10.1016/j.enbuild.2011.10.057

Hernandez, P., \& Kenny, P. (2012). Net energy analysis of domestic solar water heating installations in operation. Renewable and Sustainable Energy Reviews, 16(1), 170177. doi: http://dx.doi.org/10.1016/j.rser.2011.07.144

Ip, K., \& Miller, A. (2012). Life cycle greenhouse gas emissions of hemp-lime wall constructions in the UK. Resources, Conservation and Recycling, 69(0), 1-9. doi: http://dx.doi.org/10.1016/j.resconrec.2012.09.001

IPCC. (2013). Intergovernmental Panel on Climate Change. Working Group I Contribution to the Fifth Assessment Report of the Intergovernmental Panel on Climate Change. Climate Change 2013 - The Physical Science Basis. Cambridge University Press, Cambridge, United Kingdom and New York, NY, USA, 1535 pp.: [Stocker, T.F., D. Qin, G.-K. Plattner, M. Tignor, S.K. Allen, J. Boschung, A. Nauels, Y. Xia, V. Bex and P.M. Midgley

(eds.)].

ISO. (2006a). BSI EN ISO 14040:2006 Environmental management - life cycle assessment principles and framwork. United Kingdom: British Standard Institution.

ISO. (2006b). BSI EN ISO 14044:2006 Environmental management - life cycle assessment requirement and guidelines.

Kalogirou, S. (2009). Thermal performance, economic and environmental life cycle analysis of thermosiphon solar water heaters. Solar Energy, 83(1), 39-48. doi: http://dx.doi.org/10.1016/j.solener.2008.06.005

Koroneos, C. J., \& Nanaki, E. A. (2012). Life cycle environmental impact assessment of a solar water heater. Journal of Cleaner Production, 37, 154-161.

Martinopoulos, G., Tsilingiridis, G., \& Kyriakis, N. (2013). Identification of the environmental impact from the use of different materials in domestic solar hot water systems. Applied Energy, 102, 545-555.

Masruroh, N. A., Li, B., \& Klemeš, J. (2006). Life cycle analysis of a solar thermal system with thermochemical storage process. Renewable Energy, 31(4), 537-548. doi: http://dx.doi.org/10.1016/j.renene.2005.03.008

MBI. (2009). Commercial Modular Construction Report. Charlottesville, VA: Modular Building Institute (MBI).

Newman, I., \& Ridenour, C. (2008). Mixed methods research: Exploring the interactive continuum: Carbondale, IL: Southern Illinois University Press.

Stake, R. E. (1995). The art of case study research. Thousand Oaks, CA: Sage.

Taborianski, V. M. (2002). Avaliação da contribuição das tipologias de aquecimento de água residencial para a variação do estoque de gases de efeito estufa na atmosfera [in Portuguese]. Escola Politécnica da Universidade de São Paulo Catarina - USP, São Paulo.

Taborianski, V. M., \& Prado, R. T. A. (2004). Comparative evaluation of the contribution of residential water heating systems to the variation of greenhouse gases stock in the atmosphere. Building and Environment, 39(6), 645-652.

Thirugnanasambandam, M., Iniyan, S., \& Goic, R. (2010). A review of solar thermal technologies. Renewable and Sustainable Energy Reviews, 14(1), 312-322. 
671

672

673

674

675

676

677

678

679

680

681

682

683

684

685

686

687

688

689

690

691

692

693

694

695

Tsang, E. W. K. (2014). Case studies and generalization in information systems research: A critical realist perspective. The Journal of Strategic Information Systems, 23(2), 174186. doi: http://dx.doi.org/10.1016/j.jsis.2013.09.002

Tsilingiridis, G., \& Martinopoulos, G. (2010). Thirty years of domestic solar hot water systems use in Greece - energy and environmental benefits - future perspectives. Renewable Energy, 35(2), 490-497. doi: http://dx.doi.org/10.1016/j.renene.2009.05.001

Tsilingiridis, G., Martinopoulos, G., \& Kyriakis, N. (2004). Life cycle environmental impact of a thermosyphonic domestic solar hot water system in comparison with electrical and gas water heating. Renewable Energy, 29(8), 1277-1288.

Unilever, (2011). UK Sustainable Shower Study. Available at: http://www.unilever.co.uk/mediacentre/pressreleases/2011/sustainableshowerstudy.aspx. Retrieved July 2015.

ValentinSoftware. (2014). Available at: http://www.valentinsoftware.com/en/downloads/products. Retrieved June 2015

Weidema, B. P., Bauer, C., Hischier, R., Mutel, C., Nemecek, T., Reinhard, J., . . Wernet, G. (2013). Overview and methodology. Data quality guideline for the ecoinvent database Version 3. ecoinvent Report 1(v3). St. Gallen: The ecoinvent centre: Swiss Centre for Life Cycle Inventories.

Yin, R. K. (2009). Case study research: Design and methods, 4th ed. Thousands Oak, CA: Sage publications.

Zambrana-Vasquez, D., Aranda-Usón, A., Zabalza-Bribián, I., Jañez, A., Llera-Sastresa, E., Hernandez, P., \& Arrizabalaga, E. (2015). Environmental assessment of domestic solar hot water systems: a case study in residential and hotel buildings. Journal of Cleaner Production, 88, 29-42. 